\title{
Da Vinci Teaching
}

\section{André Simon}

Dr. med., Facharzt für Allgemeine Innere Medizin, Mitglied FMH

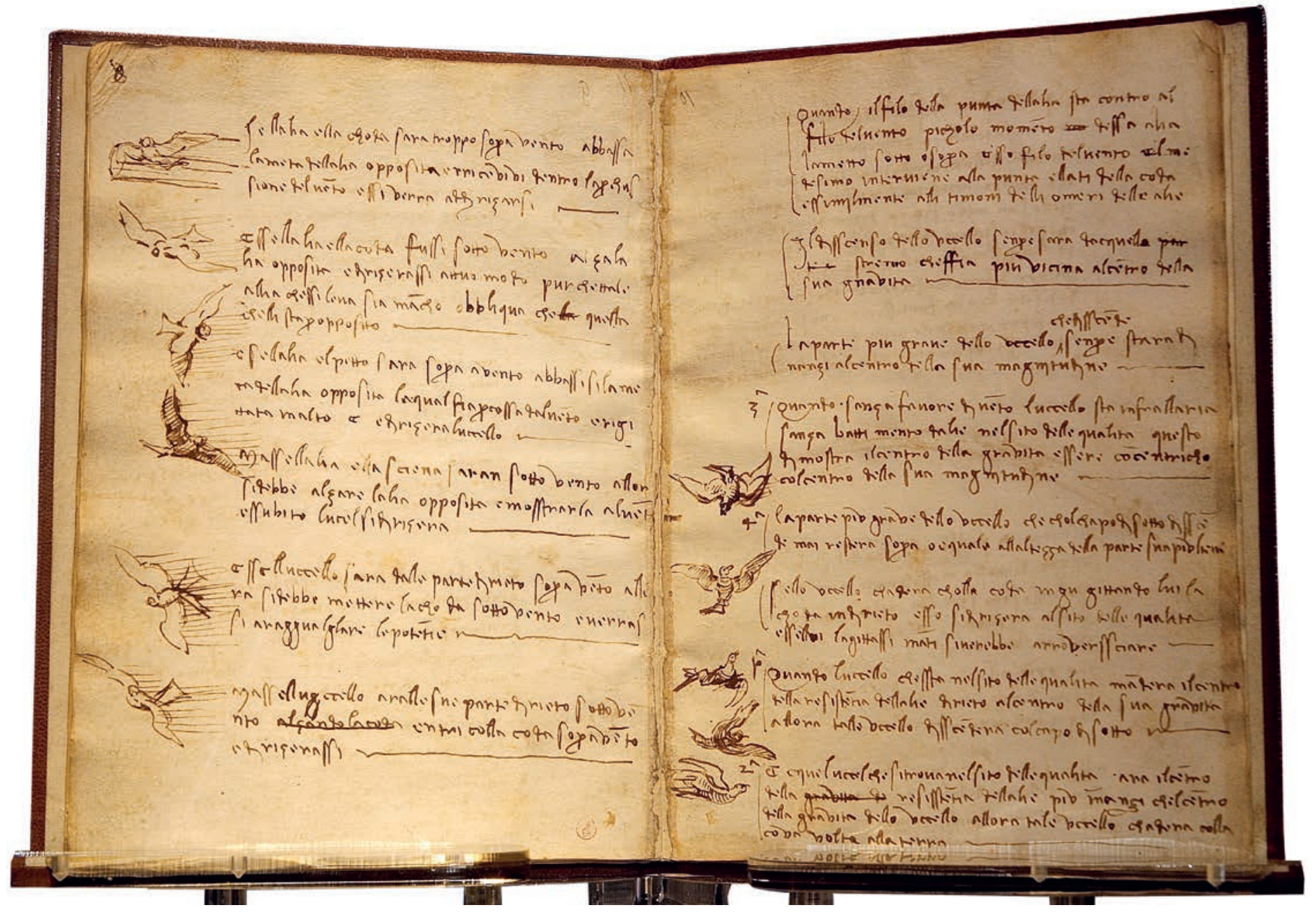

Leonardo da Vinci's Codice sul volo degli uccelli (@ Luc Viatour).

Dr. med. André Simon Facharzt für Allgemeine Innere Medizin Dörflistrasse 14

CH-8057 Zürich

andre.simon[at]hin.ch
Leonardo da Vinci (1452-1519) wrote in his notebook titled Facezie e storie that "the virtue of gratitude is said to be more [developed] in the birds called hoopoes which, knowing the benefits of life and food they have received from their parents, when they see them grow old, make a nest for them, feed them, and with their beaks pull out their old and shabby feathers. With a certain herb dropped in their old eyes they restore their sight."

It is known that Leonardo made many excursions to study the flight of the birds. Likely, by those excursions, he had observed and meticulously described the hoopoes.
This 500-years-old "fatherly lesson" could Leonardo update perhaps so:

If one day you see me old, you will notice my ignorance on new technologies. Be patient and give me the necessary time, as I had all the patience to teach you the $\mathrm{ABC}$. One day you will find that, despite my mistakes, I always wanted the best for you, I tried to pave you the way. We do not abandon our own parents at the time of real need: they have never done with us. And let us remember that life is like a wheel: sooner or later we shall fall into the ditch that we dug ourselves. 